\title{
Pensonomonoor
}

2019 , vol. $82,52-65$

http://dx.doi.org/10.12657/denbio.082.006

\author{
Karolina Pietras-Couffignal, Piotr Robakowski
}

\section{The impact of air pollution on growth features and the health of trees in Berlin}

Received: 28 August 2019; Accepted: 10 February 2020

\begin{abstract}
This study examined the impact of air pollution, and more specifically the impact of traffic, on the health of urban trees. Due to the lack of data sets, urban tree growth modeling often relies on the existing knowledge of forest. However, urban trees differ from forest trees. One of the aims of the study is to fill the lacunae in this field.

It was hypothesized that in streets with higher traffic volume, both growth parameters and health status of trees would be decreased in comparison to trees growing in streets with lower traffic volume.

Four of the most common tree species growing in Berlin were selected: Tilia cordata Mill., Acer platanoides L., Platanus acerifolia (Aiton) Willd., and Aesculus hippocastanum L. Apart from the tree age and stand position (high and low traffic volume), the height and circumference were measured and the following traits were analyzed: trunk condition, crown defoliation, leaf discoloration, the presence of hollows and nests. The streets that were selected for the analysis were located in the center of Berlin. For each species, four streets with high traffic volume and four streets with low traffic volume were chosen.

The car traffic volume had a significant impact on growth parameters. Significant differences in height and circumference between trees growing on streets with low or high traffic volume were noticed; the higher the traffic volume, the lower the tree height and circumference. This tendency is particularly visible in $P$. acerifolia, T. cordata and $A$. platanoides. This relation was observed in all species except for $A$. hippocastanum. In the conditions of high-traffic volume, $A$. platanoides is thriving revealing the smallest differences in vitality and condition of the crown, trunk and leaves. The greatest differences in the health condition of the trees among the analyzed variants of traffic intensity were observed in the case of T. cordata. Lime trees seem to be most suitable for planting in the streets with lower traffic volume, whereas A. platanoides seems most suitable for planting in the streets with high traffic volume. P. acerifolia, despite its generally good health, is suffering from several progressing diseases. It is worth considering whether it should be gradually replaced with more resistant species. Aesculus, especially A. hippocastanum, are currently the most endangered ones. An alternative to this species can be $A$. carnea.
\end{abstract}

Keywords: Acer, Aesculus, Tilia, Platanus, city trees, urban conditions

Address: K. Pietras-Couffignal, P. Robakowski, Faculty of Forestry, Poznań University of Life Science, ul. Wojska Polskiego 71 E, 60-625 Poznań, e-mail: karolina.pietras@up.poznan.pl

\section{Introduction}

Currently, almost half of the world's population lives in cities. Forecasts indicate that in 2050, around $80 \%$ of the EU population will be living in cities
(Anonymous, 2016). The specific conditions of the urban environment undoubtedly affect the quality of people's lives. According to the European Environment Agency (EEA), air pollution is the single greatest environmental health risk in Europe, more than 
half of the EU-28 population living in cities was exposed in 2013 to levels of air pollutants that exceeded World Health Organization air quality guidelines (Anonymous, 2016).

City vegetation, and especially city trees, can help to reduce pollution and improve human health by taking up a substantial amount of carbon dioxide (Nowak et al., 2006; Popek et al., 2011; Nowak et al., 2014; Łukasiewicz \& Łukasiewicz, 2016). They improve the "urban heat island effect" (Kong et al., 2014; Rötzer et al., 2019) or act as bio-filters by accumulating particles on their leaves and removing them from the atmosphere (Beckett et al., 2001; Popek et al., 2017). What is more, trees are also perceived as "the natural capital". Several studies have indicated that people are willing to pay more for a property located in a "green area" (Wolf, 2007) and that street trees produce more annual benefits, which by far exceed the trees annual maintenance costs (Wells \& Donovan, 2010). Preliminary studies suggest an average return on investment of $\$ 2.25$ for each $\$ 1$ invested in urban trees (Endreny, 2018).

However, under urban conditions, the proper functioning of vegetation is endangered: air pollution and urban-specific stressors (damaging the roots or soils by construction activities, vandalism, improper planting techniques, poor, compacted soils, water stress, etc.) have a negative impact on urban trees (Kowarik, 1990; Dmuchowski \& Badurek, 2001). As a result, the disruption in their development can occur, which can be manifested by a decrease in productivity, shortening of the vegetation period and synanthropisation (Moser et al., 2017). Therefore, it is urgent to find tree species best suited to urban conditions, which naturally must be preceded by closely observing the functioning of different species and their ability to adapt to urban areas, especially in the changing climate (Zander \& Ulrichs, 2014).

The most important elements of anthropopressure affecting the growth and development of trees in cities are air pollution, soil and climate conditions (Czarnowska et al., 1983; Biernacka et al., 1990; Balder et al., 1997; Blume, 1998; Wysocki, 2008; Breś, 2008; Dmuchowski \& Badurek, 2001; Dmuchowski et al., 2013; Baczewska et al., 2014).

In urban areas, soils serve primarily as a foundation for buildings and industrial constructions. They have peculiar characteristics such as unpredictable layering, poor structure, and high concentrations of trace elements (Tiller, 1992). There is hardly any soil in the Berlin urban area that corresponds to natural formation conditions. Natural soils have been replaced by filling material to a large extent (Schweitzer, 2010; Mekiffer, 2008). The urban soil is often contaminated by heavy metals (mainly $\mathrm{Mn}$, $\mathrm{Cd}, \mathrm{Zn}, \mathrm{Ni}, \mathrm{Cr}, \mathrm{Co}, \mathrm{Cu}, \mathrm{Pb}, \mathrm{Hg}$ ), which can be inferred to be tracers of anthropic pollution or they are inherited from parent materials (Manta et al., 2002). Roadside soil heavy metals pollution is mainly attributed to the fossil fuel combustion by high intensity traffic (Li et al., 2008). The content of calcium ions in cities exceeds even 20 times the average level of this element in arable soils, and 100 times the level in forest soils. This increases the $\mathrm{pH}$ value by up to $8 . \mathrm{Cl}$ content can be $2-5$ times higher than the threshold values for tree health (from 3 to $3.5 \mathrm{mg}$ in $100 \mathrm{~g}$ of soil) (Łukasiewicz \& Łukasiewicz, 2016).

Moreover, de-icing salts application on streets affects directly plants, but also interacts with heavy metals (Li et al., 2015).

To these elements must also be added the drying out of the soil by heating networks, the devastation of the root system and, in the case of Berlin, also the numerous constructions, the course of underground stations, tram lines. In Berlin, an additional factor that led to major changes in the structure of the soil profile was the heavy bombing of the city during World War II.

The main air pollutants in cities include dust and vapors emitted from domestic chimneys and factories, as well as automobile exhaust fumes. Sulfur compounds are of significant importance - sulfur dioxide $\left(\mathrm{SO}_{2}\right.$ being a derivative of combustion of solid and liquid fuels) and hydrogen sulfide $\left(\mathrm{H}_{2} \mathrm{~S}\right)$, nitrogen oxides $\left(\mathrm{N}_{2} \mathrm{O}, \mathrm{NO}, \mathrm{NO}_{2}\right)$. Ozone $\left(\mathrm{O}_{3}\right)$, PAN (acetyl peroxide nitrate) and nitrogen oxides which is formed as a result of the reaction between nitrogen oxides $\left(\mathrm{NO}_{\mathrm{x}}\right)$ and hydrocarbons at high temperatures and ultraviolet radiation.

Meanwhile, in Berlin traffic is the main cause of an increased levels of nitrogen oxide concentration. In 2015, road traffic alone accounted for more than $37 \%$ of the nitrogen oxide emissions in Berlin, while industrial production was responsible for less than $36 \%$ of the total emissions (Anonymous, 2018a). Since the pollution emitted by road traffic enters the atmosphere close to the ground, it contributes greatly to air pollution for humans and vegetation. Additional weakening factors for plants are PM (particular matters) with particles $<100 \mu \mathrm{m}$. These fine particles settle on leaves and may penetrate the leaf tissues, which cause the blockage of stomata (Nowak et al., 2006; Łukasiewicz \& Łukasiewicz, 2016; Popek et al., 2017). Different species react differently to this type of contamination. On the one hand, trees and shrubs contribute significantly to the reduction of particulate matter, mainly by accumulating pollutants on the leaf surface; on the other hand, these dust particles settle on plants and make it difficult for them to breathe, transpire and assimilate (Popek et al., 2011).

These factors significantly limit the choice of the species and varieties of trees that can be planted in cities (Szyprowski, 2000). The accumulation of several factors of stress, such as drought and salinity, 
has a much greater negative effect on trees than the presence of only one factor. This is manifested by, for example, necrosis on leaves, the reduction of leaf surface, premature leaf fall, and the appearance of fungal diseases and harmful insects (Flückiger \& Braun, 1999; Ordóñez-Barona et al., 2018).

The aim of this study was to determine the influence of traffic-based air pollution on the growth, health status and vitality of city trees in Berlin.

The general condition of trees growing in streets with low traffic volume was compared with the condition of trees growing in streets with high traffic volume. It was hypothesized that in streets with higher traffic volume and air pollution both growth parameters and health status of trees would be reduced in comparison to the trees growing in streets with lower traffic volume. The deteriorated condition of trees will be manifested by the lower values of the circumference at breast height and tree height, more frequent occurrence of pathogens, worse crown condition, quality of trunk, defoliation and discoloration of leaves. We classified the study tree species with regard to their tolerance to traffic-based pollution.

Deeper scientific knowledge concerning the requirements of the individual tree species and their contribution to the urban climate, with regard to climate change and the increasing problem of tree condition in urban areas, is required.

Due to the lack of data sets, urban tree growth modeling often relies on the existing knowledge of forest standards (Aguaron \& McPherson, 2012; Peper et al., 2014; Pretzsch et al., 2015; Moser et al., 2017). However, urban trees differ from forest trees. One of the aims of the study is to fill the lacunae in this field.

\section{Material and Methods}

\section{Study area}

Berlin is one of the greenest capitals in Europe. On average, there are around 82 trees per kilometer

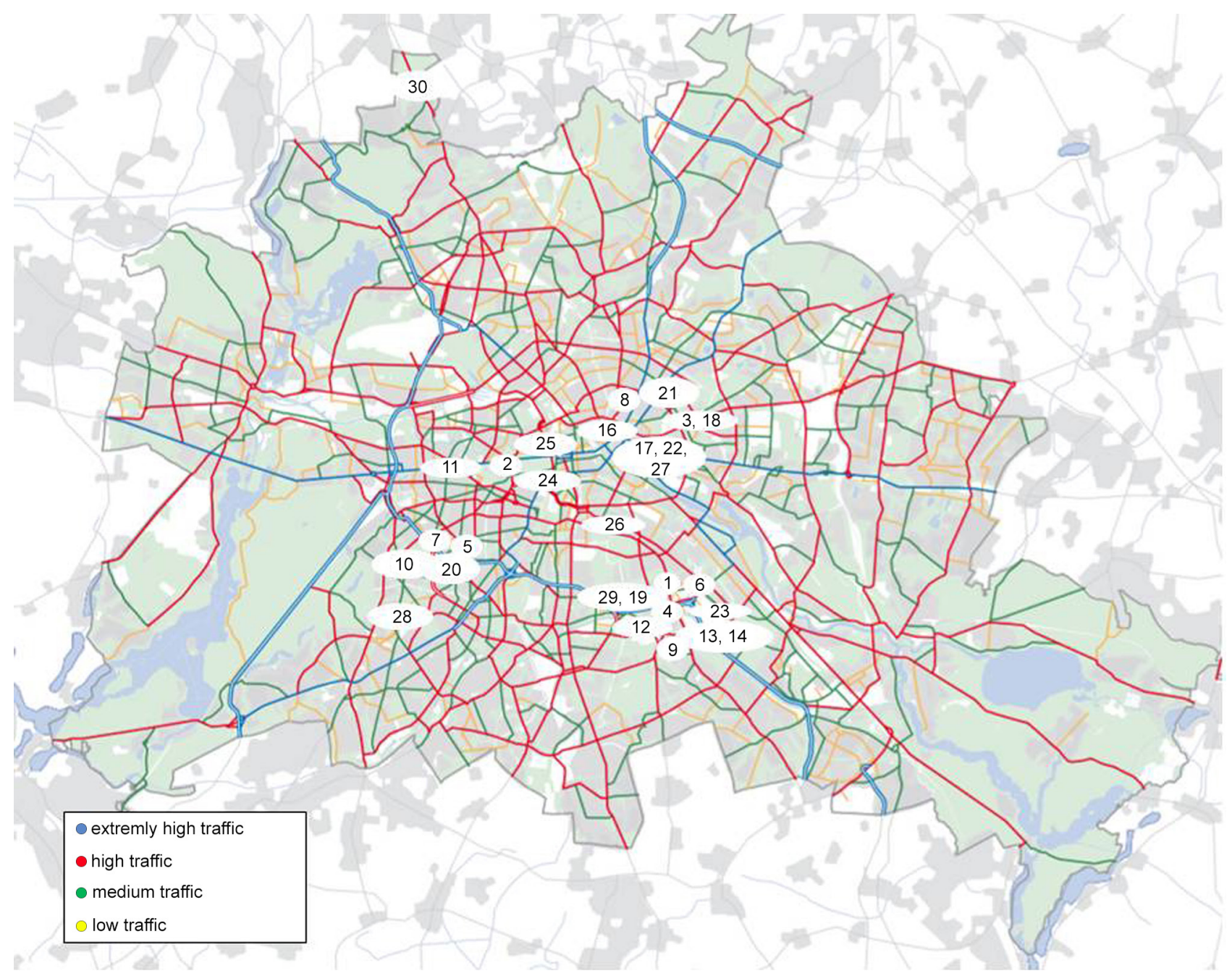

Fig. 1. Localization of the studied trees in Berlin. The numbers correspond to the streets where focal trees are growing (Table 1). The colors represent the traffic volume

With the authorisation of the publisher, with changes. Umweltatlas Berlin, 2015, Traffic-related emissions. 
of the street (Balder, 2013, Fachsymposium Stadtgrün, Berlin). Berlin has been rebuilt and now has already exceeded the stock of street trees decimated during World War II, which fell from around 411.000 in 1939 to around 161,000 trees in 1946. Today, there are 432.937 trees -21.000 more than before the war (Anonymous, 2018b). There are more than 50 different species of trees on the streets of Berlin. The five most common species are Tilia 35\%, Acer 20\%, Quercus 9\%, Platanus 6\% and Aesculus 5\%. They account for about $75 \%$ of the urban tree population (Anonymous, 2018c).

The climate in Berlin is temperate and continental. The average annual temperature is $+9.1{ }^{\circ} \mathrm{C}$ and the average annual rainfall is $581 \mathrm{~mm}$. July $(+14.3$ ${ }^{\circ} \mathrm{C}$ ) and August $\left(+14.1^{\circ} \mathrm{C}\right)$ are the warmest months, while January $\left(-1.9^{\circ} \mathrm{C}\right)$ and February $\left(-1.5^{\circ} \mathrm{C}\right)$ are the coldest ones. In addition to some natural fluctuations, it can also be seen that over the last 120 years the annual temperature has risen significantly. While the average annual temperature in the early measuring years was still around $8{ }^{\circ} \mathrm{C}$, average values between 9.5 and $10.5{ }^{\circ} \mathrm{C}$ were usually reached in the recent years (Anonymous, 2015a). Based on phenological studies of trees in Europe, the earlier sprouting of trees by 0.3 days per annum and an extension of the average vegetation period by ten days per annum has been proven (Schreiner, 2017).

In June 2017, a month before the start of the measurements, the climatic conditions in Berlin were as follows: the average temperature of the month $18.2^{\circ} \mathrm{C}$, precipitation $159 \mathrm{~mm}$, insolation 239 hours (Landeskompetenzzentrum Forst Eberswalde Report, Information der Hauptstelle für Waldschutz 12.09.2017). In Berlin, apart from the important volume of traffic, the following factors exert a major impact on the health of trees: changes in the soil profile due to the bombardment of the city during World War II, soil drainage by district heating networks, root system devastation, large number of buildings, metro stations, tram lines and a very high number of dogs (ca. 100 000, Berlin Senat Ordnungsamt, 2019).

For the purpose of the experiment, streets from the center of Berlin were selected (Table 1, Fig. 1). For each species, 4 streets with a high traffic volume and 4 streets with a low traffic volume were chosen. In this way, four true repetitions of each traffic volume variant per species were obtained except for Aesculus hippocastanum $\mathrm{L}$ with three high-traffic volume streets and three low-traffic volume streets. The reason behind this difference was due to the difficulty in finding four streets with ten $A$. hippocastanum trees of similar age.

The following factors were taken into account in the street selection process: an average daily traffic volume, emission of nitrogen dioxide $[\mathrm{g} /(\mathrm{m} /$ day $)]$, emission of nitrogen oxides $[\mathrm{g} /(\mathrm{m} /$ day $)]$, emission of exhaust particles $\left[\mathrm{g} / \mathrm{m} /\right.$ day], emission of $\mathrm{PM}_{10}[\mathrm{~g} /$ $(\mathrm{m} /$ day $)]$, carbon dioxide emission $[\mathrm{g} /(\mathrm{m} / \mathrm{day})]$, and finally "Evaluation of emission levels based on $\mathrm{NO}_{\mathrm{x}}$ and PM10" (Acronym: Evaluation NOx and $\mathrm{PM}_{10}$ ).

Out of 15 streets (or street parts) classified as "low traffic", two were classified as "far below average" based on $\mathrm{NO}_{\mathrm{x}}$ and $\mathrm{PM}_{10}$, other streets chosen for the study had a low emissions level, i.e. under "far below average" (Table 3).

The areas classified in this study as "streets with high traffic volume" evaluated emission levels based on $\mathrm{NO}_{\mathrm{x}}$ and $\mathrm{PM}_{10}$ from "average" to "far above average" (Table 4).

Table 1. Location of the trees in Berlin. Numbers from 1 to 30 represents the location of the street on the map

\begin{tabular}{|c|c|c|c|}
\hline \multicolumn{3}{|c|}{ High volume traffic streets } & \multirow{2}{*}{$\begin{array}{c}\text { Low volume traffic street } \\
\text { Tilia cordata }\end{array}$} \\
\hline \multicolumn{2}{|r|}{ Tilia cordata } & \multirow{2}{*}{\multicolumn{2}{|c|}{$\begin{array}{c}\text { Tilia cordata } \\
\text { Torstr. } 8 \text { pcs }\end{array}$}} \\
\hline 1 & Kienitzerstr. 10 pcs & & \\
\hline 2 & Droysenstr. 10 pcs & 17 & Mollstr. /Otto Braunstr. 10 pcs \\
\hline 3 & Schliemannstr. 10 pcs & 18 & Greifswalderstr. 10 pcs \\
\hline 4 & Oderstr. 10 pcs & 19 & Hermannstr. 10 pcs \\
\hline \multicolumn{3}{|c|}{ Acer platanoides } & Acer platanoides \\
\hline 5 & Davoserstr. 8 pcs & 20 & Breitestr. 10 pcs \\
\hline 6 & Oderstr. (West) 10 pcs & 21 & Eberswalderstr. 6 pcs \\
\hline 7 & Kirchstr. 7pcs & 22 & Mollstr./Otto Braunstr. 10 pcs \\
\hline 8 & & 23 & Ederstr./Sonnenallee 8 pcs \\
\hline \multicolumn{3}{|c|}{ Platanus acerifolia } & Platanus acerifolia \\
\hline 9 & Schillerpromenade 9 pcs & 24 & Adenauerplatz 10 pcs \\
\hline 10 & Reichenhallerstr. 10 pcs & 25 & Kudam/Breitenbachplatz 10 pcs \\
\hline 11 & Platannenallee 10 pcs & 26 & Zossenerstr. 10 pcs \\
\hline 12 & Eschesheimerstr. 10 pcs & 27 & Mollstr./Otto Braunstr. 9 pcs \\
\hline \multicolumn{3}{|c|}{ Aesculus hippocastanum } & Aesculus hippocastanum \\
\hline 13 & Siegfriedstr. (West side) 10pcs & 28 & Königin Louise 10 pcs \\
\hline 14 & Siegfriedstr. (East side) 10 pcs & 29 & Hasenheide 10 pcs \\
\hline 15 & Stubenrauchstr. 10 pcs & 30 & Zeltingerplatz 10 pcs \\
\hline
\end{tabular}




\section{Material and Methods}

In July 2016, in Berlin, 282 trees were chosen for the analysis. Four of the most common genera of trees in Berlin were analyzed: Tilia, Acer, Platanus, Aesculus. The following tree species were evaluated with regard to their responses to air pollution: Tilia cordata Mill., Acer platanoides L., Platanus acerifolia (Aiton), Aesculus hippocastanum L.

In addition to the tree age and stand position (high and low traffic volume), the height and circumference were measured and the following traits were analyzed: trunk condition, crown defoliation, leaf discoloration, presence of hollows and nests. In the

Table 2. Average age and type of localization of the tree species

\begin{tabular}{lccc}
\hline \multicolumn{1}{c}{ Species } & Traffic volume & Number of trees & Average age \\
\hline T. cordata & High traffic & 38 & 41.6 \\
T. cordata & Low traffic & 40 & 42.3 \\
A. hippocastanum & High traffic & 28 & 46.2 \\
A. hippocastanum & Low traffic & 29 & 40.8 \\
A. platanoides & High traffic & 34 & 37.3 \\
A. platanoides & Low traffic & 35 & 44.1 \\
P. acerifolia & High traffic & 39 & 38.0 \\
P. acerifolia & Low traffic & 39 & 42.8 \\
\hline
\end{tabular}

case of established pathogens, samples were taken for laboratory analysis.

The circumference of the tree was measured with a measuring tape band at a height of $1.3 \mathrm{~m}$. Tree height measurements were carried out with a Nikon Forestry Pro Laser Rangefinder with an accuracy of $0.5 \mathrm{~m}$. While evaluating the crown, the main criteria were the degree of defoliation and discoloration, and the number of dead branches or thinning of the crown. The evaluation of the trunk took into consideration, general health condition, external signs of leakage, tumors, slats, presence of fungi and mechanical damage (caused by construction works, cars, vandalism).

For the analytical purpose, the obtained results following the degree scale of the damage (scale for trunk, crown and leaves):

- 5 - very good condition, tree intact (up to $10 \%$ defoliation)

- 4 - good condition, slight or medium damaged tree (11-30\% defoliation)

- 3 - poor condition (31-60\% defoliation)

- 2 - very poor condition (60-90\% defoliation)

- 1 - dead (over $90 \%$ defoliation) or cut.

Table 3. Emissions and daily traffic volume on "low traffic streets"

\begin{tabular}{|c|c|c|c|c|c|c|c|}
\hline $\begin{array}{l}\text { Name of the } \\
\text { street section }\end{array}$ & $\begin{array}{l}\text { Average daily } \\
\text { traffic volume }\end{array}$ & $\begin{array}{c}\text { Emission of } \\
\mathrm{NO}_{2}[\mathrm{~g} /(\mathrm{m} / \text { day })]\end{array}$ & $\begin{array}{c}\text { Emission of NO } \\
{[\mathrm{g} /(\mathrm{m} / \text { day })]}\end{array}$ & $\begin{array}{c}\text { Emission of ex- } \\
\text { haust particles } \\
{[\mathrm{g} / \mathrm{m} / \text { day }]}\end{array}$ & $\begin{array}{c}\mathrm{PM}_{10}[\mathrm{~g} /(\mathrm{m} / \\
\text { day })]\end{array}$ & $\begin{array}{c}\mathrm{CO}_{2} \\
{[\mathrm{~g} /(\mathrm{m} / \text { day })]}\end{array}$ & $\begin{array}{c}\text { Evaluation NOx } \\
\text { and } \mathrm{PM}_{10}\end{array}$ \\
\hline Droysenstr. & 2617 & 0.22 & 1.02 & 0.02 & 0.08 & 0.55 & far below average \\
\hline Platanenallee & 6300 & 0.65 & 2.89 & 0.06 & 0.28 & 1.35 & far below average \\
\hline
\end{tabular}

With the authorization of the publisher, with changes. Senatsverwaltung für Stadtentwicklung und Wohnen Berlin, 2015, Umweltatlas Berlin, Traffic-related Emissions, 2015.

Table 4. Emissions and daily traffic volume on "high traffic streets"

\begin{tabular}{|c|c|c|c|c|c|c|c|}
\hline $\begin{array}{c}\text { Name of the street } \\
\text { section }\end{array}$ & $\begin{array}{l}\text { Average daily } \\
\text { traffic volume }\end{array}$ & $\begin{array}{c}\text { Emission of } \\
\mathrm{NO}_{2} \\
{[\mathrm{~g} /(\mathrm{m} / \text { day })]}\end{array}$ & $\begin{array}{c}\text { Emission of } \\
\mathrm{NO} \\
{[\mathrm{g} /(\mathrm{m} / \text { day })]}\end{array}$ & $\begin{array}{c}\text { Emission of } \\
\text { exhaust particles } \\
{[\mathrm{g} / \mathrm{m} / \text { day }]}\end{array}$ & $\begin{array}{c}\mathrm{PM}_{10} \\
{[\mathrm{~g} /(\mathrm{m} / \text { day })]}\end{array}$ & $\begin{array}{c}\mathrm{CO}_{2} \\
{[\mathrm{~g} /(\mathrm{m} / \text { day })]}\end{array}$ & $\begin{array}{c}\text { Evaluation NOx } \\
\text { and } \mathrm{PM}_{10}\end{array}$ \\
\hline Torstr. & 31590 & 4.82 & 20.22 & 0.34 & 1.85 & 7.78 & far above average \\
\hline Otto-Braun-Str. & 41130 & 6.27 & 26.41 & 0.48 & 2.47 & 10.74 & far above average \\
\hline Greifswalder Str. & 24570 & 3.47 & 13.83 & 0.27 & 1.32 & 6.02 & above-average \\
\hline Hermannstr. & 24840 & 6.73 & 25.81 & 0.30 & 1.85 & 7.64 & far above average \\
\hline Breite Str. & 8910 & 1.54 & 6.57 & 0.09 & 0.57 & 2.09 & average \\
\hline Eberswalder Str. & 13230 & 2.10 & 9.14 & 0.16 & 0.81 & 3.63 & average \\
\hline Mollstr. & 33030 & 4.50 & 19.24 & 0.35 & 1.97 & 7.67 & far above average \\
\hline Ederstr/Sonnenallee & 24660 & 4.58 & 17.88 & 0.26 & 1.51 & 6.18 & above-average \\
\hline Kurfürstendamm & 26100 & 6.39 & 25.64 & 0.33 & 1.79 & 8.22 & far above average \\
\hline $\begin{array}{l}\text { Budapesterstr./ } \\
\text { Breitscheidplatz }\end{array}$ & 30420 & 5.61 & 23.51 & 0.38 & 1.84 & 8.80 & far above average \\
\hline Zossenerstr. & 13860 & 1.87 & 7.77 & 0.13 & 0.62 & 3.34 & average \\
\hline Otto-Braun-Str. & 41130 & 6.27 & 26.41 & 0.48 & 2.47 & 10.74 & far above average \\
\hline Englerallee & 19530 & 3.19 & 13.33 & 0.24 & 1.10 & 5.50 & above-average \\
\hline Hasenheide & 22050 & 2.48 & 11.25 & 0.23 & 1.09 & 4.89 & above-average \\
\hline ZeltingerPlatz & 7560 & 1.30 & 4.94 & 0.07 & 0.32 & 2.12 & average \\
\hline
\end{tabular}

With the authorization of the publisher, with changes. Senatsverwaltung für Stadtentwicklung und Wohnen Berlin, 2015, Umweltatlas Berlin, Traffic-related Emissions, 2015. 


\section{Data analysis}

The data were examined for normality using the Shapiro-Wilk's test and homogeneity of variance following Levene's test. Since the data did not meet the conditions of the analysis of variance, the two-sample Mann-Whitney U test was performed at the level of significance $\alpha=0.05$ (Mann \& Whitney, 1947).

\section{Results}

The results indicate that the volume of car traffic has had a significant impact on the growth parameters. Considerable differences in height and circumference between trees growing in streets with low or high traffic volume were noticed, which was observed for all species with the exception of $A$. hippocastanum. The tendency is clear, the higher the traffic volume is, the smaller the circumference becomes. The difference in circumference between the low and high traffic volume is particularly remarkable for $P$. acerifolia, followed by A. platanoides and T. cordata (Fig. 2). A similar tendency is observed between the height of trees and the volume of traffic, the higher the traffic volume, the smaller the height. An important difference can be observed for $P$. acerifolia, followed by $T$. cordata and A. platanoides (Fig. 3). P. acerifolia reacts most negatively to air pollution caused by the traffic volume compared with $T$. cordata and A. platanoides. In contrast, $A$. hippocastanum did not show any significant signs of reacting to the traffic volume.

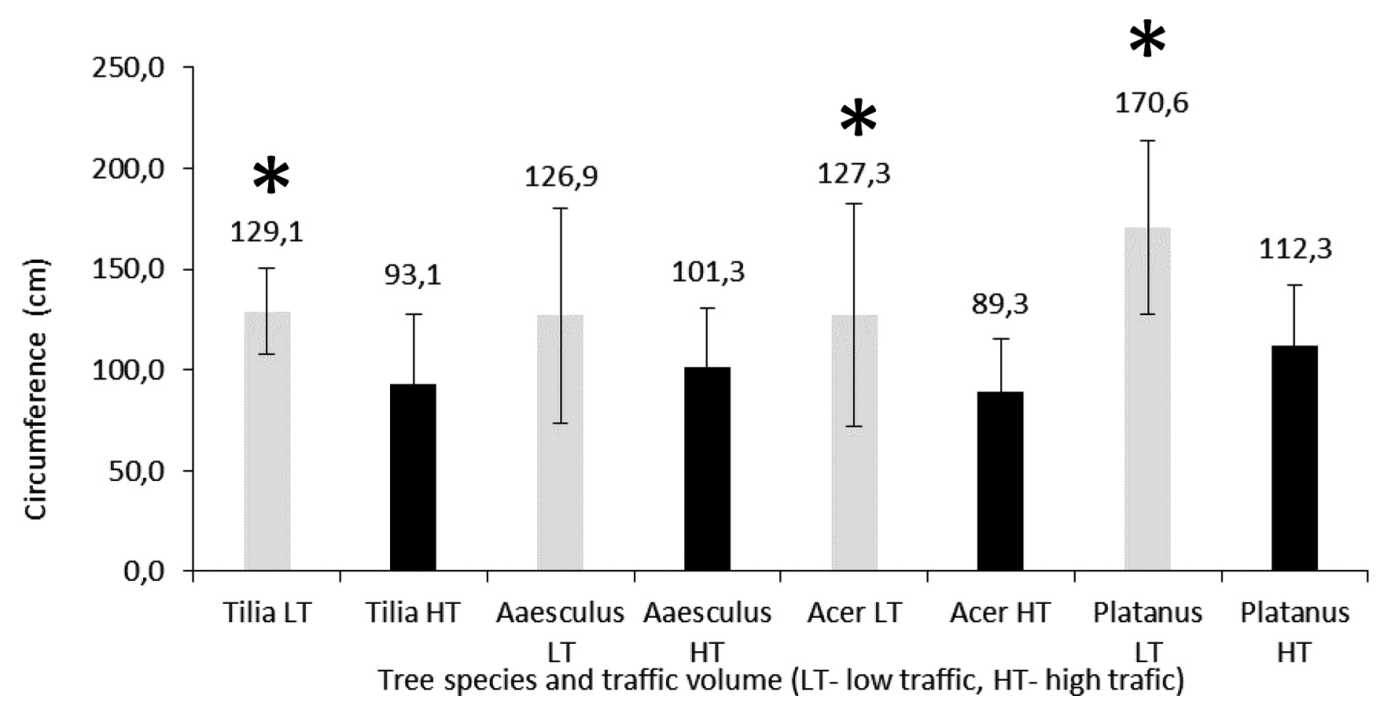

Fig. 2. The circumference of trees growing in the streets of Berlin with low or high traffic volume (means \pm SD). Asterisks indicate that the means are significantly different in Mann-Whitney $\mathrm{U}$ test at $\mathrm{P}<0.05$

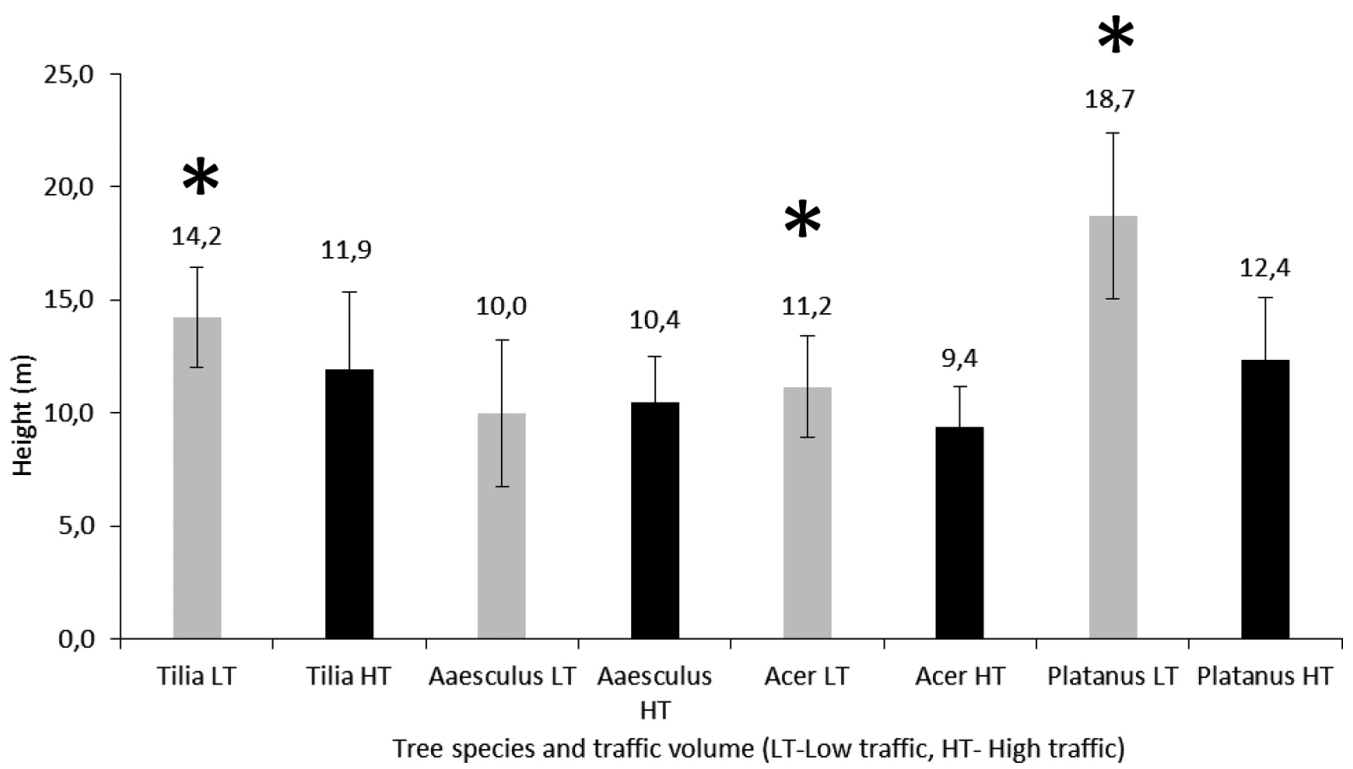

Fig. 3. The height of trees growing in the streets of Berlin with low or high traffic volume (means \pm SD). Asterisks indicate that the means are significantly different in Mann-Whitney $\mathrm{U}$ test at $\mathrm{P}<0.05$ 
In addition, the data analysis displayed that trees growing in streets with small traffic volume live longer or are left at the site longer because of their better condition, which is true for all species except for A. hippocastanum. The average tree age of the studied species is provided in Table 2 .

\section{Condition of trees}

The health status of the four tested species was assessed using the damage scale from 1 to 5 . For $T$. cordata all the examined parameters: height, circumference, crown condition, trunk and leaf condition were better in the variant with low traffic volume (Fig. 4). In the low traffic variant T. cordata was characterized by a better crown condition (minor defoliation), trunk and leaf condition than in the case of the variant with a high traffic volume. Also, the number of nests was higher: 12 nests on trees with low traffic volume as compared to 4 on trees with a high traffic volume. The average health assessment of the low traffic variant was 4.5 and for the high traffic variant was 3.9.

In the case of $A$. platanoides, the situation is not as clear as $T$. cordata. However, the examined trees show also a higher vitality in the variant with a low traffic volume (Fig. 5). The condition of the crown and leaves for $A$. platanoides growing in streets with less traffic is better. Only the condition of trunks in the study trees was slightly better than in the variant with a high traffic volume. Similarly, as in the case of T. cordata, birds chose trees growing in streets with a lower traffic volume for their nests (relation 6 to 1). Probably the noise caused by car traffic has a major impact on their choice.

The average health assessment of the low traffic was 4 whereas for the high traffic variant was 3.8.

$P$. acerifolia trees growing in high-traffic streets are characterized by a crown and trunk in a worse condition (Fig. 6). As far as the health status of leaves is concerned, in both variants it was very comparable, in both cases it was noted with 4 . The health condition can be explained by a very large number of $P$. acerifolia infected with mildew, which was identified in both variants. It is interesting to note that birds avoid nesting on plane trees in Berlin, regardless of the volume of the car traffic. The average health assessment of the low traffic was 4.5 and for the high traffic variant it was 4.2 .

The vitality assessment of $A$. hippocastanum suggests that also this species finds better growth conditions under lower pressure of traffic pollution (Fig. 7). However, it showed by far the worst vitality and overall health condition of all species in both variants. Undoubtedly, it can be explained by the gradation of Cameraria ohridella Deschka \& Dimić over several years and numerous trunk damage. Interestingly, no bird nests were found on the analyzed $A$. hippocastanum. The average health condition in the low traffic was 3.3 and in the high traffic variant 3.2.

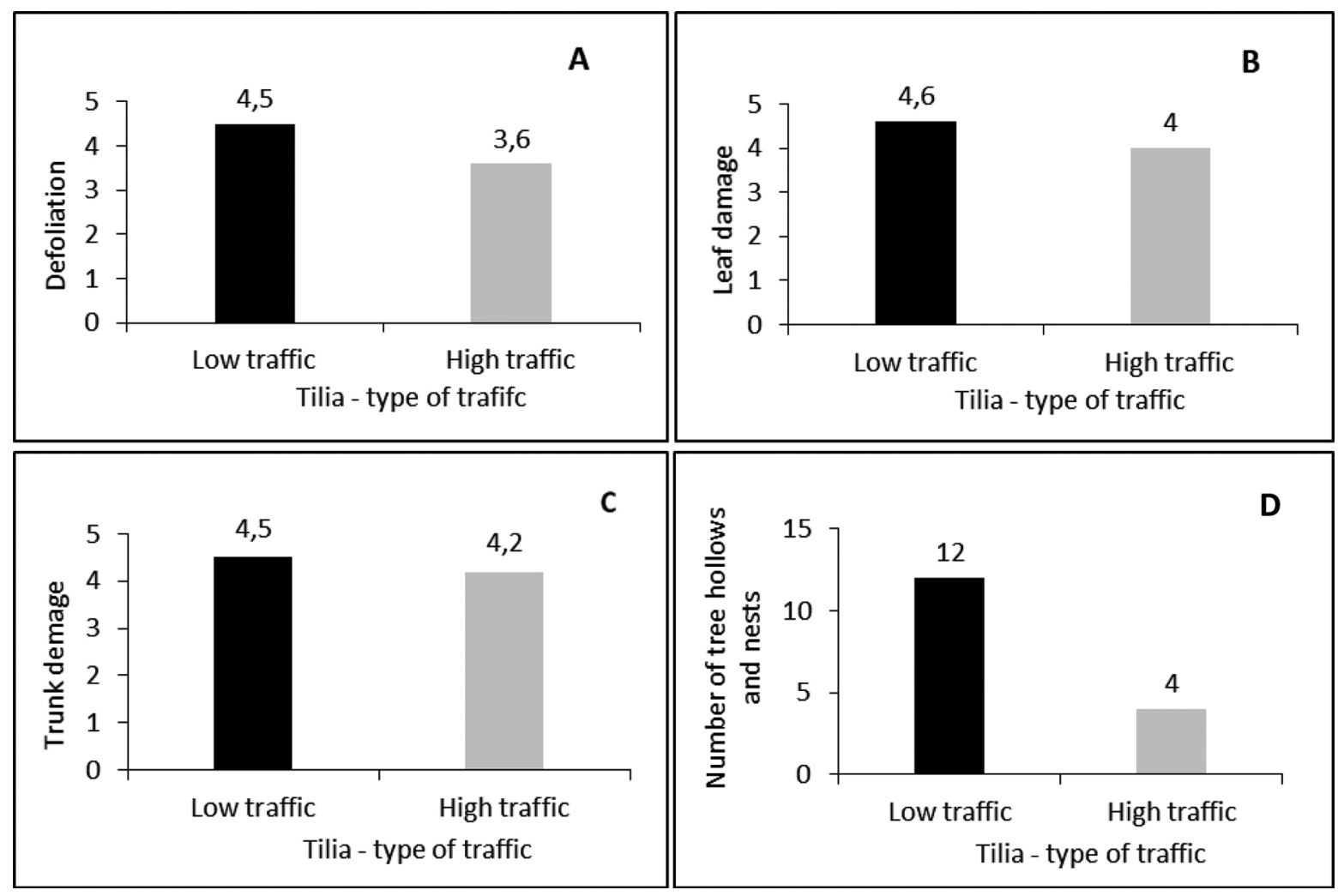

Fig. 4. Health condition of $T$. cordata according to the traffic volume. Scale from 0 to 5 , where 5 is the best score 


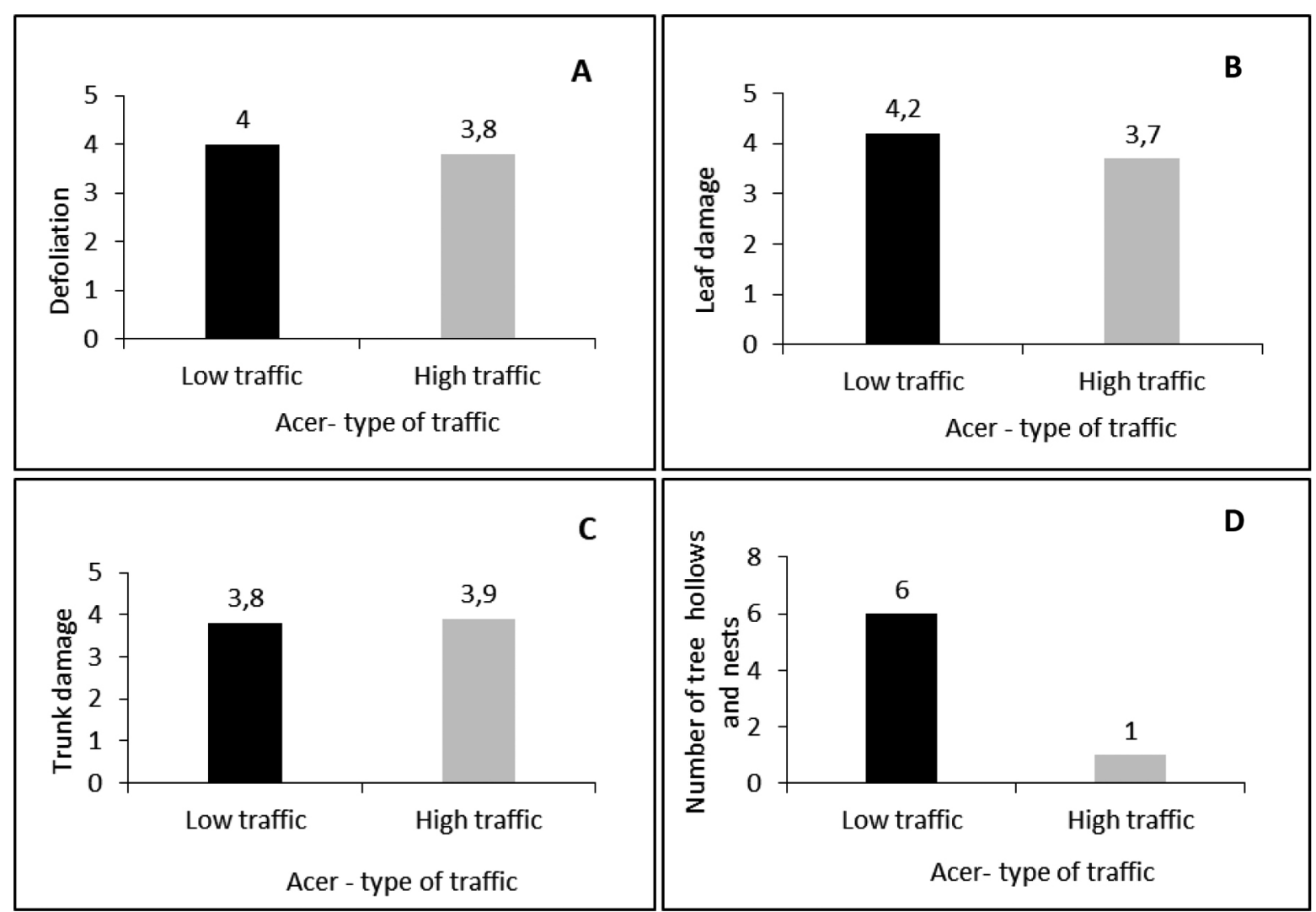

Fig. 5. Health condition of A. platanoides according to the traffic volume. Scale from 0 to 5 , where 5 is the best score

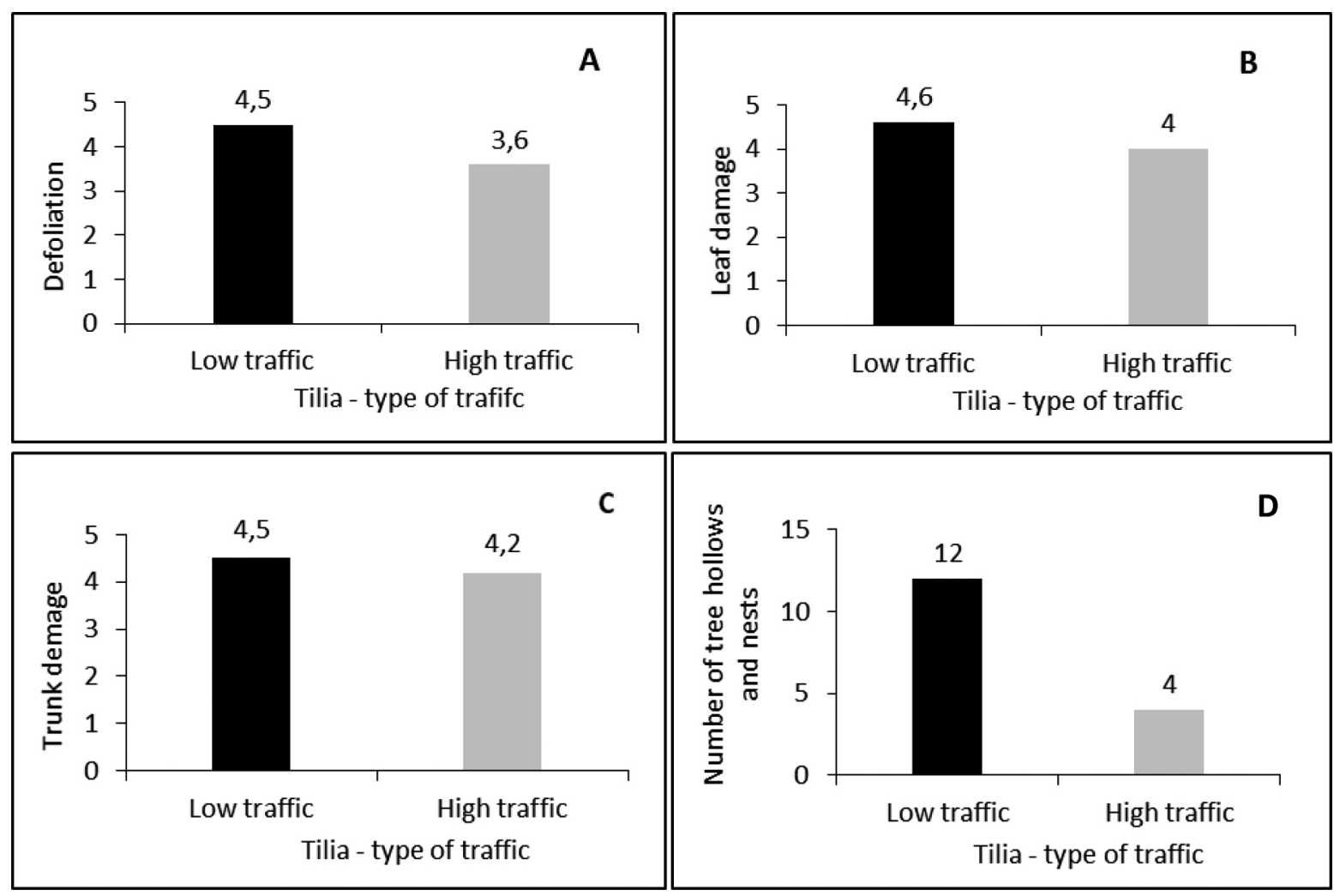

Fig. 6 . Health condition of P. acerifolia according to the traffic volume. Scale from 0 to 5 , where 5 is the best score 


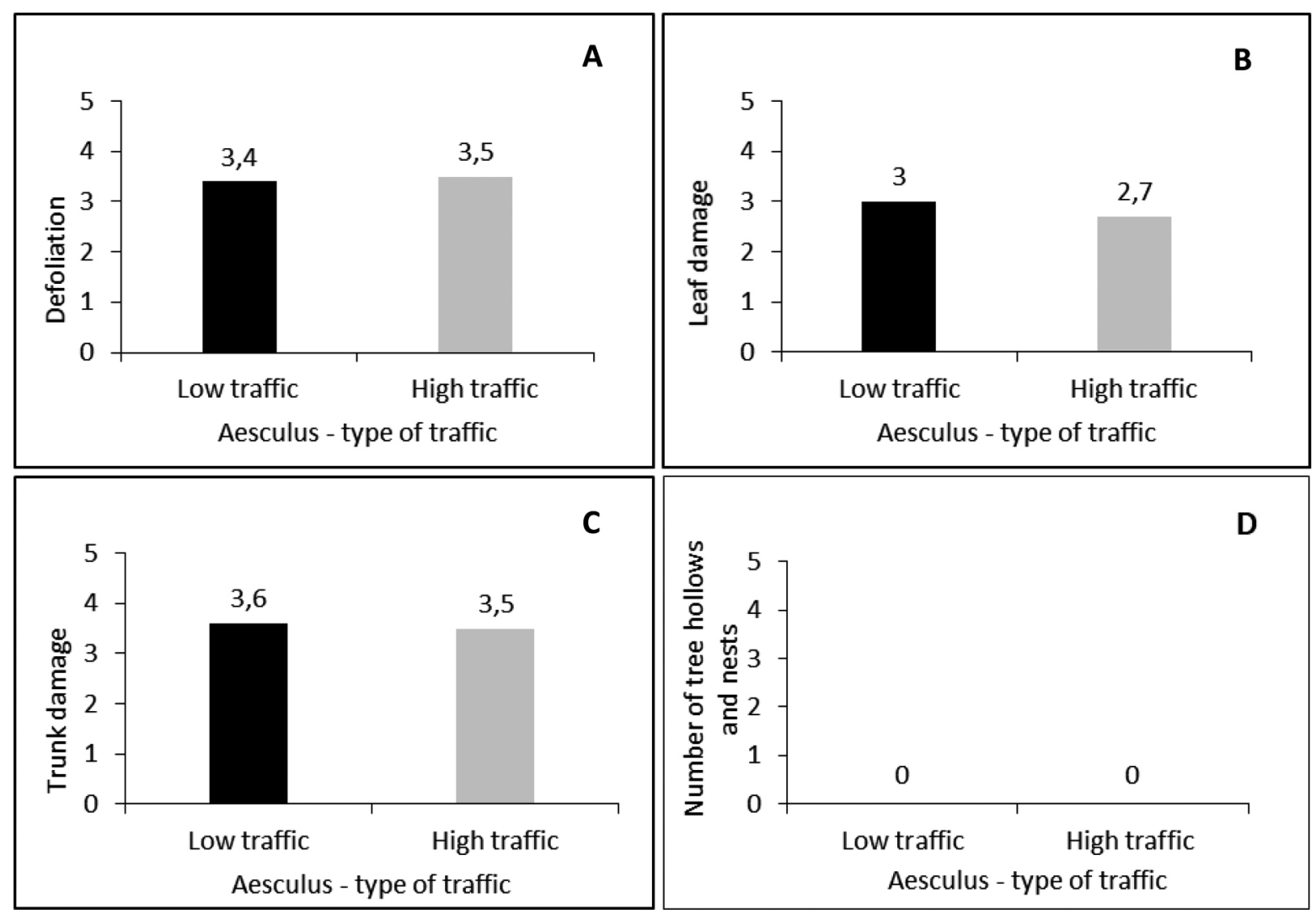

Fig. 7. Health condition of $A$. hippocastanum according to the traffic volume. Scale from 0 to 5 , where 5 is the best score

\section{Abiotic and biotic disorders in city trees}

The study trees indicated an amount of damage caused by pathogens and abiotic factors, of which the most common ones are leaf discoloration, black linden bloom (caused by aphids and fungi), powdery mildew, water stress damage (e.g. wilting, leaf discoloration), and $\mathrm{SO}_{2}$ intolerance damage (injury in the form of foliar necrosis). The most common damage on $T$. cordata leaves were necrosis and black coating, dribbles; on Acer and Platanus, there were mildew and leaf necrosis. Aesculus, however, were in mass attacked by Cameraria ohridella.

In the samples taken between $25^{\text {th }}$ July 2017 and $15^{\text {th }}$ August 2017 and examined based on macroscopic and microscopic symptoms in the Forest Protection Service in Łopuchówko, following pathogens were found:

1. Tilia
(a) powdery mildew - Phyllactina guttata (Wallr.) Lev.
(b) discoloration due to water stress
(c) discoloration due to $\mathrm{SO}_{2}$ intolerance

2. Acer
(a) powdery mildew - Phyllactina guttata (Wallr.) Lev.
(b) leaf perforation - Asteromella platanoidis (Sacc.) Petr.

(c) leaf anthracnose - Aureobasidium apocryptum (Ellis \& Everh.) Herm.-Nijh.

\section{Platanus}

(a) powdery mildew - Erysiphe platani HOWE.

\section{Discussion}

In the present study, there was evidence that out of the four urban tree species studied, three showed a general health status that can be evaluated as good. These were P. acerifolia, T. cordata and A. platanoides due to the decreasing tolerance to air pollution.

A significant difference was found in the tree height and circumference depending on the localization of the tree. P. acerifolia reacted more strongly to high intensity of air pollution caused by traffic, followed by Tilia and Acer. The statistical differences for Aesculus turned out to be insignificant.

Not only air pollution may reduce trees vitality in Berlin. It is highly plausible that the urban soil of the streets with the high traffic volume has had a higher concentration of heavy metals which have been toxic for the study trees (Birke \& Rauch, 2000; Manta et al., 2002; Li et al., 2015). In particular, urban soils are enriched in lead that is highly toxic for roadside trees (Czerniawska-Kusza et al., 2004; Biasioli et al., 2006). 
However, results of a study in the city of Palermo where a map of pollutant distribution were constructed for the whole urban area suggest that vehicle traffic represents the most important pollutant source for the studied urban environment (Manta et al., 2002). We may assume that the situation is similar in Berlin where there is no longer any industry that could cause contamination with heavy metals.

Additionally, snow removal salts may cause leaf chlorosis, necrosis and defoliation of crowns (Czerniawska-Kusza et al., 2004). Damaging effects of heavy metals on trees can be increased through an interaction with de-icing salts (Li et al., 2015). The soil salinity induced an increase in $\mathrm{Na}^{+}$and $\mathrm{Cl}^{-}$content in tree leaves, but, on the other hand, it reduced the accumulation of $\mathrm{K}+, \mathrm{Ca} 2+$, and $\mathrm{Mg} 2+$ ions (Czerniawska-Kusza et al., 2004).

However, this aspect is limited in the case of Berlin, if compared with other cities. The use of salt is prohibited in West Berlin since 1987 and since 1991 in the former East Berlin. Nowadays, only the BSR (municipal disposal company) may use wet salt on some important road surfaces (Anonymous, 2013).

Another important factor which may have an influence on city trees is the so called "Urban Heat Island" Effect. In the case of Berlin, data from the reference area Berlin-Dahlem (situated in the south-west city part) confirm this tendency. However, it should be pointed out, that in the center of Berlin this difference is probably even more important. For the reference period 1971-2000, the annual mean air temperature was $9.6^{\circ} \mathrm{C}$ (range of variation $8.1-10.9^{\circ} \mathrm{C}$ ), 0.5 to $1.0 \mathrm{~K}$ higher than outside Berlin. Compared to five other long-term test sites in the rural Brandenburg area, Dahlem is the warmest and wettest location (Schweitzer, 2010). This difference of temperature can have an influence on the development of pathogens on trees in the city (Tubby \& Webber, 2010).

The reduction of height and circumference of trees which is reported in our present study has resulted from higher air pollution and soil contamination in streets with the greater traffic volume compared with trees growing under a lower pressure of pollutants.

The research revealed that of the observed species, $P$. acerifolia and T. cordata tolerate urban conditions best, although $T$. cordata is particularly recommended for planting on sites with a lower traffic volume; in this variant the health condition of the trees was 4.5 and in the case of high traffic volume 3.9. Moreover, due to the growth characteristics, T. cordata trees are much better suited for planting on narrower streets than P. acerifolia, what is more, they also perform well in conditions of high traffic volume (score 4.2). In Warsaw, Dmuchowski et al. (2013) also pointed out that T. cordata accumulated much more $\mathrm{Cl}^{-}$and $\mathrm{Na}^{+}$ than A. pseudoplatanus and A. hippocastanum. Furthermore, linden trees in Warsaw are among the species most prone to dying. It seems that the situation of this species in Berlin is better. In addition, regarding the capacity of capturing PM, it was recognized that T. cordata, the iconic tree of Berlin, is less efficient then coniferous species and Pinus sylvestris L. in particular (Willis \& Petrokofsky, 2017). In busy streets, it is, therefore, advisable to plant other tree species. However, city trees are effective to reduce pollution, but only if care is taken to avoid trapping pollutants beneath their crowns (Pugh et al., 2012). That's why planting Platanus, especially with all the growth characteristics of the crowns, in streets with high volume traffic, should be reconsidered.

Moreover, long-term observations of Platanus trees revealed a dramatic decrease in the life span of crowns between 1979 and 2000 (Fietz \& Burger, $2015)$. From the position of the healthiest of the Berlin trees (only about 6\% damaged in 1979) to the most damaged (about $77 \%$ in 2000). A significant improvement was observed during the evaluation in 2005. In 2010, the vitality deteriorated again, and during the observation in 2015, a slight improvement in the vitality of $P$. acerifolia crowns of all ages was observed (Fietz \& Burger, 2015). The observations in 2017 showed a renewed deterioration of the crown condition in plane trees due to a massive infestation with Erysiphe platani HOWE mildew. In 2012, this pathogen was identified at many different locations in Berlin (Schreiner \& Feilhaber, 2013). Only six years later, it was found on the all scrutinized Platanus trees. In other parts of Europe, this problem has also been observed (Carretier, 2017). A study by the Plant Protection Office (Pflanzenschutzamt) in Berlin found that pruned trees are particularly vulnerable to mildew infestation; the heavier was the pruning, the more infected the trees (Schreiner \& Feilhaber, 2013).

Another threat to Platanus is the disease caused by Splanchnonema platani (Ces.) Barr., which causes plane trees to die. This disease, known as Massaria, was first detected in Germany in 2003 after a hot and particularly dry summer. Even thick branches die within a few weeks and can become a major threat (Dujesiefken \& Kehr, 2008). It is advisable to have the infected branches removed, especially when pruning leads to a more intensive infestation with powdery mildew (Schreiner \& Feilhaber, 2013). Therefore, it is worth considering whether this species should not be gradually replaced by others, more resistant to disease.

The results of our observations can be compared with the results of the last Street tree condition report (Straßenbaum-Zustandsbericht) (Fietz \& Burger, 2015). For 40 years, city trees in Berlin have been evaluated at five-year intervals. Defoliation and discoloration of leaves are the main evaluation criteria to determine the vitality level of the 
tree crown. However, the trees studied in the report (Fietz \& Burger, 2015) are not divided according to traffic intensity. In 2015, the genus Tilia proved to be most resistant to damage $-60.2 \%$ of the analyzed Tilia crowns were assessed as undamaged; followed by Platanus $50.1 \%$. Meanwhile, Acer with $61.9 \%$ of the damaged crowns and Aesculus with $52.6 \%$ were classified as the trees with the weakest vitality of crowns (Fietz \& Burger, 2015). Our results for Tilia and Platanus are similar to those published in the Report from 2015: in both cases, Tilia was the healthiest tree, especially in the low volume traffic variant.

According to our research, A. hippocastanum, whose general condition was estimated at 3-3.5 (i.e. bad + ), is in the worst state in the current conditions. Therefore, it is more often being replaced by A. carnea. However, it is not clear what has been the main cause of the $A$. hippocastanum's deteriorated condition. It can be suspected that air pollution is not the source of this state, but rather biotic factors, particularly the gradation of Cameraria ohridella. In addition to defoliation, a repeated gradation of this insect is also responsible for the reduction in the radial growth of the attacked trees.

An invasive control method, i.e. trunk injection with pesticides, tested in Kórnik, Poland, presented good results (Jagiełło et al., 2019). However, considering the number of infected trees in Berlin, the associated costs and the introduction of chemical agents into green areas, its use on a wider scale might prove unrealistic.

Moreover, the future of this species seems to be endangered; for example, in recent years a highly progressive Aesculus disease caused by Pseudomonas syringae pv. aesculi has been observed in Berlin. Interestingly, these bacteria also attack other trees from this genus (A. hippocastanum, Aesculus x carnea Hayne., Aesculus flava Sol., (Aesculus pavia L.). This disease not only leads to the death of the tree within a few years, but also spreads quite quickly. In 2018, 24 outbreaks of the disease were identified in Berlin (Anonymous, 2018d).

The observations conducted in Berlin reveal that urban trees are facing many problems. Due to the changing climate, Berlin and other cities around the world, are looking for new plants that are better adapted to the harsh urban conditions (Roloff, 2013; Moser et al., 2016; Fellhölter et al., 2018).

In a recent survey of the city of Berlin, a total of 23 tree species have been identified by the districts as alternatives to Tilia sp. and A. platanoides, mainly at roadsides. Ulmus resista and Liquidamber styraciflua L. are frequently planted. Among the small-crowned trees, Amelanchier arborea (F. Michx.) Fernald is often planted (Anonymous, 2015b).

The final conclusion concerning the tree species which are most suitable for the changing urban conditions requires, however, further research and observation (Burley et al., 2019; Núñez-Florez et al., 2019). In addition, the introduction of new species in northern European cities on a larger scale (Zander \& Ulrichs, 2014; Böll, 2018), it may be worth considering species which have already been planted in southern cities of the continent, and which respond well to drought stress and the high levels of insolation.

\section{Conclusions}

- There is a strong relationship between traffic congestion and the height and circumference of trees growing in Berlin.

- P. acerifolia reacts most negatively to air pollution caused by the traffic volume compared with T. cordata and $A$. platanoides.

- P. acerifolia, despite its generally good health, is suffering from several progressing diseases. It is worth considering whether it should be gradually replaced by more resistant species.

- In the conditions of high traffic volume, A. platanoides is thriving revealing the smallest differences in vitality and condition of the crown, trunk and leaves.

- Aesculus, especially A. hippocastanum, are currently the most endangered. An alternative to this species can be $A$. carnea.

- The highest differences in the general condition of trees between the analyzed variants of traffic intensity were observed in the case of T. cordata. At present, lime trees seem to be most suitable to be planted in streets with lower traffic volume.

- Trees growing in streets with little traffic live longer or are left on the site longer because of their better condition. This is true for all species except for $A$. hippocastanum

\section{Acknowledgements}

We thank Radosław Cieślak from Forest Protection Service in Łopuchówko (ZOL) for the analyses of the pathogens and Martin Schreiner from Pflanzenschutzamt for meetings and information about the current problems of city trees in Berlin.

The publication is co-financed within the framework of Ministry of Science and Higher Education programme as "Regional Initiative Excellence" in years 2019-2022, project number 005/RID/2018/19 nauki leśne/6".

\section{References}

Aguaron E \& McPherson EG (2012) Comparison of methods for estimating carbon dioxide storage by 
Sacramento's urban forest: Carbon Sequestration in Urban Ecosystems (ed. by R Lal \& B Augustin) Springer, New York, USA, pp. 43-71.

Anonymous (2013) Gesetz über Naturschutz und Landschaftspflege von Berlin (Berliner Naturschutzgesetz - NatSchG Bln). http://gesetze.berlin.de/jportal/?quelle= jlink\&query $=$ NatSchG + BE\&psml=bsbeprod. psml\&max $=$ true.

Anonymous (2015a) EFRE Projekt. Stadtklima Berlin Abschlussbericht GIS-gestützte Modellierung von stadtklimatisch relevanten Kenngrößen auf der Basis hochaufgelöster Gebäude- und Vegetationsdaten“. GEO-NET GmbH, Senatsverwaltung für Stadtentwicklung und Umwelt, Berlin, Germany. http://www.stadtentwicklung.berlin.de/ umwelt/umweltatlas/download/Projektbericht StadtklimaBerlin_SenStadtUm_IIID_2015.pdf.

Anonymous (2015b) Problemanalyse $\mathrm{zu}$ Berliner Stadtbäumen. Fragebogenauswertung „Stadtgrün 2015“. Pflanzenschutzamt Berlin, Berlin, Germany. https://www.berlin.de/senuvk/pflanzenschutz/stadtgruen/de/download/ueberwachung/ problemanalyse stadtbaeume 2015.pdf.

Anonymous (2016) Eurostat. Statistical Book. Urban Europe Statistics on Cities, Towns and Suburbs. Publications office of the European Union, Luxembourg. https://ec.europa.eu/eurostat/documents/3217494/7596823/KS-01-16-691-EN-N. pdf/0abf140c-ccc7-4a7f-b236-682effcde10f.

Anonymous (2018a) Long-Term Development of Air Quality. Senatsverwaltung für Stadtentwicklung und Wohnen, Berlin, Germany. https://www. stadtentwicklung.berlin.de/umwelt/umweltatlas/ed312 03.htm.

Anonymous (2018b) Straßenbäume in Berlin. Bestandsveränderung in Berlin und den Bezirken einschl. Zu- und Abgänge 2018. Bericht Nr. 131. Referat Freiraumplanung und Stadtgrün, Senatsverwaltung für Umwelt, Verkehr und Klimaschutz, Berlin, Germany. https://www.berlin. de/senuvk/umwelt/stadtgruen/stadtbaeume/de/ daten_fakten/downloads/ausw_131.pdf.

Anonymous (2018c) Straßenbäume in Berlin. Bestand nach Hauptgattungen in den Berliner Bezirken. Bericht Nr. 139. Referat Freiraumplanung und Stadtgrün, Senatsverwaltung für Umwelt, Verkehr und Klimaschutz, Berlin, Germany. https://www.berlin.de/senuvk/umwelt/stadtgruen/stadtbaeume/de/daten_fakten/downloads/ ausw_139.pdf.

Anonymous (2018d) Merkblatt. Pseudomonas syringaepv. aesculi - Absterbeerscheinungen an Kastanien. Pflanzenschutzamt Berlin, Berlin, Germany. https://www.berlin.de/senuvk/pflanzenschutz/ stadtgruen/de/ueberwachung/pseudomonas. shtml.
Balder H, Ehlebracht K \& Mahler E (1997) Strassenbäume: Planen - Pflanzen - Pflegen am Beispiel Berlin. Patzer Verlag, Berlin, Germany.

Baczewska AH, Dmuchowski W, Józwiak A, Gozdowski D, Brągoszewska P, Dąbrowski P \& Swiezewska E (2014) Effect of salt stress on prenol lipids in the leaves of Tilia 'Euchlora'. Dendrobiology 72:177-186. doi:10.12657/denbio.072.015.

Beckett KP, Freer-Smith PH \& Taylor G (2001) Particulate pollution capture by urban trees: effect of species and windspeed. Global Change Biology 6: 995-1003. doi:10.1046/j.13652486.2000.00376.x.

Berlin Senat Ordnungsamt (2019) https://www. berlin.de/ba-treptow-koepenick/politik-und-verwaltung/aemter/ordnungsamt/artikel.86083. php.

Biasioli M, Barberis R \& Ajmone-Marsan F (2006) The influence of a large city on some soil properties and metals content. Science of the Total Environment 356: 154-164.

Birke M \& Rauch U (2000) Urban geochemistry: Investigations in the Berlin metropolitan area. Environmental Geochemistry and Health 22: 233248. doi:10.1023/A:1026554308673.

Blume HP (1998) Böden: Stadtökologie (ed. by H Sukopp \& R Wittig) Fischer, Stuttgart, Germany, pp. $168-185$.

Breś W (2008) Czynniki antropopresji powodujące zamieranie drzew w krajobrazie miejskim. Nauka Przyroda Technologie 2: 31.

Böll S (2018) “Projekt Stadtgrün 2021" Selektion, Anzucht und Verwendung von Gehölzen unter sich ändernden klimatischen Bedingungen. Abschlussbericht zum Forschungsvorhaben Nr. KL/17/03. https://www.lwg.bayern.de/mam/ cms06/landespflege/dateien/abschlussbericht_ stadtgruen_2018-74_in.pdf.

Burley H, Beaumont LJ', Ossola A, Baumgartner JB, Gallagher R, Laffan S, Esperon-Rodriguez M, Manea A \& Leishman MR (2019) Substantial declines in urban tree habitat predicted under climate change. Science of the Total Environment 685: 451-462.

Carretier D (2017) Bulletin de santé du végétal ZNA. Édition Midi-Pyrénées. Hors-série BILAN 2017.

Czarnowska K, Gworek B, Kozanecka T, Latuszek B \& Szafranska E (1983) Heavy metals content in soils as indicator of urbanization. Polish Ecological Studies 9: 63-79.

Czerniawska-Kusza I, Kusza G \& Dużyński M (2004) Effect of deicing salts on urban soils and health status of roadside trees in the Opole Region. Environmental Toxicology 19: 296-301. doi:10.1002/ tox. 20037.

Dmuchowski W \& Badurek M (2001) Stan zieleni przyulicznej w Warszawie na podstawie wielolet- 
nich obserwacji i doświadczeń Ogrodu Botanicznego. Materiały z konferencji „Zieleń Warszawy, problemy i nadzieje - 5 lat później. CZRB PAN, Warsaw, pp. 19- 28.

Dmuchowski W, Baczewska A, Gozdowski D \& Brągoszewska P (2013) Effect of salt stress on the chemical composition of leaves of different species in urban environment. Fresenius Environmental Bulletin 22: 987994. doi:10.1080/15226514.2017.1328394.

Dujesiefken D \& Kehr R (2008) Die Massaria-Krankheit in Deutschland als Folge des Klimawandels? Stand des Wissens und Empfehlungen für den weiteren Umgang mit der Platane: Jahrbuch der Baumpflege (ed. by D Dujesiefken) Verlag Haymarket Media, Braunschweig, Germany, pp. 4956.

Endreny TA (2018) Strategically growing the urban forest will improve our world. Nature Communications 9: 1160.

Fellhölter G, Schreiner M, Ulrichs C \& Zander M (2018) Erste Ergebnisse zur Eignung neuer Baumarten an stark belasteten Straßenstandorten in Berlin-Neukölln. ProBaum 2: 7-12.

Fietz M \& Burger H (2015) Straßenbaum-Zustandsbericht Berliner Innenstadt 2015. Senatsverwaltung für Stadtentwicklung, Berlin, Germany. https://www.berlin.de/senuvk/umwelt/stadtgruen/stadtbaeume/downloads/strb_zustandsbericht2015.pdf.

Flückiger W \& Braun S (1999) Stress factors of urban trees and their relevance for vigour and predisposition for parasite attacks. Acta Horticulturae 496: 325-334. doi:10.17660/ActaHortic.1999.496.40.

Jagiełło R, Walczak U, Iszkuło G, Karolewski P, Baraniak E \& Giertych MJ (2019) Impact of Cameraria ohridella on Aesculus hippocastanum growth and long-term effects of trunk injection with pesticides. International Journal of Pest Management 65: 33-43. doi:10.1080/09670874.2018.145463.

Kowarik I (1990) Some response of flora and vegetation to urbanization in Central Europe: Urban ecology. Plants and plant communities in urban environments (ed. by H Sukopp, S Hejny \& I Kowarik) SPB Academic Publishing, Den Haag, Holland, pp. 45-74.

Li F, Fan Z, Xiao P, Oh K, Ma X \& Hou W (2008) Contamination, chemical speciation and vertical distribution of heavy metals in soils of an old and large industrial zone in Northeast China. Environmental Geology 57: 1815-1823. doi:10.1007/ s00254-008-1469-8.

Li F, Zhang Y, Fan Z \& Oh K (2015) Accumulation of de-icing salts and its short-term effect on metal mobility in urban roadside soils. Bulletin of Environmental Contamination and Toxicology 94: 525-531.
Łukasiewicz A \& Łukasiewicz S (2016) Rola i kształtowanie zieleni miejskiej. Wydawnictwo Naukowe UAM, Poznań, Poland.

Mann HB \& Whitney DR (1947) On a test of whether one of two random variables is stochastically larger than the other. Annals of Mathematical Statistics 18: 50-60.

Manta SD, Angelone M, Bellanca A, Neria R \& Sprovieri M (2002) Heavy metals in urban soils: a case study from the city of Palermo (Sicily), Italy. Science of The Total Environment 300: 229-243. doi:10.1016/S0048-9697(02)00273-5.

Mekiffer B (2008) Eigenschaften urbaner Böden Berlins. Statistische Auswertung von Gutachtendaten und Fallbeispiele. Doctoral thesis. Technische Universität Berlin. https://www.boden.tu-berlin. de/fileadmin/fg77/_pdf/_diss/mekiffer_diss.pdf.

Moser A, Rötzer T, Pauleit S \& Pretzsch H (2016) The urban environment can modify drought stress of small - leaved lime (Tilia cordata Mill.) and black locust (Robinia pseudoacacia L.). Forests 7: 1-20. doi:10.3390/f7030071.

Moser A, Rötzer T, Pauleit S \& Pretzsch H (2017) Stadtbäume: Wachstum, Funktionen und Leistungen - Risiken und Forschungsperspektiven. Allgemeine Forst- und Jagdzeitung 188: 94-111. doi:10.23765/afjz00020006.

Nowak DJ, Crane DE \& Stevens JC (2006) Air pollution removal by urban trees and shrubs in the United States. Urban Forestry \& Urban Greening 4: 115-123. doi:10.1016/j.ufug.2006.01.007.

Nowak DJ, Hirabayashi S, Bodine A \& Greenfield E (2014) Tree and forest effects on air quality and human health in the United States. Environmental Pollution 193: 119-129.

Núñez-Florez R, Pérez-Gómez U \& Fernández-Méndez F (2019) Functional diversity criteria for selecting urban trees. Urban Forestry \& Urban Greening 38: 251-266.

Peper PJ, Alzate CP, McNeal JW \& Ashemi JH (2014) Allometric equations for urban ash trees (Fraxinus spp.) in Oakville, Southern Ontario, Canada. Urban Forestry \& Urban Greening 13: 175-183.

Popek R, Gawrońska H \& Gawroński SW (2011) Zdolności krzewów do akumulacji mikropyłów z powietrza. Nauka Przyroda Technologie 5: 124.

Popek R, Łukowski A, Bates C \& Oleksyn J (2017) Accumulation of particulate matter, heavy metals, and polycyclic aromatic hydrocarbons on the leaves of Tilia cordata Mill. in five Polish cities with different levels of air pollution. International Journal of Phytoremediation 19: 1134-1141. doi: 10.1080/15226514.2017.1328394.

Pretzsch HP, Biber E, Uhl J, Dahlhausen T, Rötzer J, Calendentey T, Koike T, Vancon A, Chavanne T, Seifert B, Dutoit C, Farnden C \& Pauleit S (2015) Crown size and growing space requirement of 
common tree species in urban centers, parks, and forests. Urban Forestry \& Urban Greening 14: 466-479.

Pugh TAM, MacKenzie RA, Whyatt JD \& Hewitt CN (2012) Effectiveness of green infrastructure for improvement of air quality in urban street canyons. Environmental Science \& Technology 46: 7692-7699. doi:10.1021/es300826w.

Roloff A (2013) Bäume in der Stadt. Ulmer Verlag, Stuttgart, Germany.

Rötzer T, Rahman MA, Moser-Reischl A, Pauleit S \& Pretzsch H (2019) Process based simulation of tree growth and ecosystem services of urban trees under present and future climate conditions. Science of The Total Environment 676: 651-664.

Ordóñez-Barona C, Sabetski V, Millward AA \& Steenberg J (2018) De-icing salt contamination reduces urban tree performance in structural soil cells. Environmental Pollution 234: 562-571.

Schreiner M \& Feilhaber I (2013) Echter Mehltau (Erysiphe platani HOWE) und Schnittmassnahmen an Platanen in Berlin. Wissenschaftliche Kurzberichte. Jahrbuch der Baumpflege 7: 239-245.

Schreiner M (2017) Pflanzenschutz im öffentlichen Raum am Beispiel Berlin. Neue Landschaft 2: 38-42.

Schweitzer K (2010) Naturnahe Böden im Berliner Stadtgebiet. Referenz für anthropogene Bodenentwicklung oder Beispiel für anthropogene Bodenveränderungen. Boden- und Standort- verhältnisse auf den Versuchsfeldern der landwirtschaftlichen Lehr- und Forschungsstation der Humboldt-Universität zu Berlin. Berliner Geographische Arbeiten 117: 13-22.

Szyprowski J (2000) Próba doboru gatunków i odmian drzew do nasadzeń przyulicznych w Warszawie. Ogrodnictwo 3: 27-29.

Tiller KG (1992) Urban soil contamination in Australia. Australian Journal of Soil Research 30: 937-957.

Tubby KV \& Webber JF (2010) Pests and diseases threatening urban trees under a changing climate. Forestry 83: 451-459.

Wells G \& Donovan G (2010) Calculating the green in green: What's an urban tree worth? Science Findings 126. Portland, OR: U.S. Department of Agriculture, Forest Service, Pacific Northwest Research Station.

Willis KJ \& Petrokofsky G (2017) The natural capital of city trees. Science 356: 374-376.

Wolf KL (2007) City trees and property values. Arborist News 16: 34-36.

Wysocki C (2008) Miasto jako specyficzne środowisko życia roślinności. Nauka Przyroda Technologie 2: 25 .

Zander M \& Ulrichs C (2014) Alleebäume unter Klimastress - neue Sortimente für die Zukunft (ed. by R Bloch, J Bachinger, R Fohrmann \& R Pfriem) Oekom Verlag, München, Germany, pp. 211-222. 